 \\ $\underline{\text { Recenzije i prikazi }}$
}

i ljubavi, a što već i samim time naznačuje ozbiljnost i usmjerenost pothvata, ali, stava sam, isto tako i hvalevrijedan primjer procesa stvaranja. (Naime, danas se često događa da zbog neoliberalnog terora /i tijekom visokoškolske edukacije/ ljudi svojim istraživanjima pristupaju površno i na brzinu, pa ne čudi da kao rezultat toga nastaju nedorečeni, površni, nerazrađeni, konfuzni, promašeni i sl. tekstovi, prije svega zbog nedostatka sazrijevanja misli i znanja o onome o čemu se želi i pokušava pisati.)

Hrvatsko filozofsko društvo, Zagreb 2016.

U vremenu kada filozofijom, sve agresivnije i opresivnije, dominira nešto što se sve teže može nazvati filozofijom (čast vrijednim izuzecima!), sama pojava knjige koja se bavi važnim misliteljem tzv. kontinentalne filozofije, odnosno s filozofijskom misli (koja je u nas vrlo malo u radovima obrađivana) jednog od stupova njemačkog klasičnog idealizma, ne samo da izaziva radost nego predstavlja i važan događaj. Još ako se k tomu pribroji da je knjigu Razvoj Fichteova jenskoga sustava transcendentalne filozofije $u$ kontekstu pokantovskih rasprava napisala mlada osoba

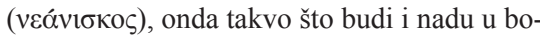
lju budućnost.

Ljudevit Fran Ježić, autor navedene knjige, diplomirani je filozof i lingvist, a svemu filozofijskom i sl. pomodarstvu usprkos, vlastiti je filozofijski istraživački rad posebice usmjerio prema antičkoj grčkoj filozofiji i njemačkom klasičnom idealizmu. Štoviše, navedeno približava zainteresiranima i u sklopu nastave, kao docent na Katedri za povijest filozofije Odsjeka za filozofiju Filozofskog fakulteta Sveučilišta u Zagrebu. Upravo na temelju dijela Ježićevih filozofijskih interesa i stremljenja nastaje i navedeno djelo, odnosno plod što se kao pupoljak nazreo u koleginu diplomskom radu, a zatim kao cvijet u njegovoj doktorskoj disertaciji. Dakle, očito je kako knjiga Razvoj Fichteova jenskoga sustava transcendentalne filozofije u kontekstu pokantovskih rasprava predstavlja rezultat višegodišnjeg istraživanja

Ježićev prvijenac (koji se proteže na 318 stranica) temeljno grade šest poglavlja, sedamnaest potpoglavlja i pet potpotpoglavlja, a kojima prethodi predgovor i popis kratica pojedinih u knjizi korištenih djela, dok nakon zaključnog poglavlja dolaze bogat popis korištenih izvora (što primarnih što sekundarnih, i to uglavnom na njemačkom, ali i na engleskom, francuskom, hrvatskom i hrvatsko-srpskom/srpsko-hrvatskom jeziku), dva autorova vrijedna prijevoda (jedan je Fichteovih Aforizama o religiji i deizmu, iz 1790., dok je drugi Fichteove recenzije djela Aenesidemus, iz 1794. godine), sažetak djela na engleskom jeziku i kazalo imena. Također, knjigu krasi i devet ilustracija: s portretima u njoj predstavljenih filozofa, dvije naslovnice (Aenesidemusa i Kritike čistoga uma) i jednim izvatkom iz novina stranice Fichteove recenzije Aenesidemusa.

U svakom slučaju, radi se o knjizi koja, prateći razvoj Fichteova jenskoga sustava transcendentalnoga idealizma ili znanstvoslovlja (Wissenschaftshlehre) u užem smislu, temeljno u kontekstu pokantovskih rasprava u kojima i Fichte aktivno sudjeluje, pruža vrijedne informacije o njegovu nastanku i prvotnom razvoju, kao i o samom Fichteu (između ostaloga smatram vrijednom, tj. može biti poticajna naznačena Fichteova /prvotna/ samokritičnost, njegov pristup nastavi, ali rekao bih i uloga same nastavne djelatnosti na kristaliziranje njegove misli itd.). Dakle, Ježić nam temeljno predstavlja sam Fichteov jenski sustav filozofije, odnosno njegov ustroj, temeljne postavke i smisao, Fichteov odnos 
s najznačajnijim neposrednim filozofijskim prethodnicima (neki su od njih u nas gotovo pa i nepoznati /i u okvirima stručne javnosti/ te po prvi put ozbiljnije predstavljeni), kao i određene probleme $u$ razvoju sustava, $i$ to $u$ kontekstu rasprava neposrednih prethodnika. Osim vrijednosti navedenoga, naznačio bih po meni još jednu bitnu značajku ove knjige, a to je da neizravno pruža i važan uvid $u$ to kako za istinitije shvaćanje, tumačenje i sl. misli određenog/e mislitelja/ice nije dovoljno biti upoznat samo s njegovim/zinim stvaralaštvom, životom i općim duhom vremena u kojem djeluje, nego i s konkretnim osobama, raspravama, recenzijama, prepiskama i sl. o onome što se obrađuje, tj. što izravno ili neizravno često vrlo značajno djeluje na stvaratelja ili stvarateljicu.

U cilju boljeg uvida o čemu se u knjizi radi, u nastavku se usmjeravam sažetom prikazu ili naznačivanju njezina sadržaja, prateći postavljenu strukturu, odnosno redoslijed izlaganja materije. U tom bih kontekstu naznačio kako sama struktura Ježićeva teksta i nije previše čvrsto u svim dijelovima izvedena, ali što nužno i ne mora predstavljati propust, posebice jer je tekst čitak i jezično promišljen.

Tako u prvom ili uvodnom poglavlju (Uvod: O pristupu Fichteovoj jenskoj filozofiji u njenu kontekstu), u kojemu prikazuje svoj pristup, Ježić naznačuje da se odlučio ponuditi nešto što je u Hrvatskoj, u kontekstu Fichtea, gotovo pa i nepoznato, dok se u inozemstvu ozbiljnije istražuje tek zadnjih desetljeća (na neke nas od značajnijih djela u ovom dijelu knjige i usmjerava). Dakle, navodi kako je temeljno nastojao, a potvrđujem da je i uspio, približiti pokantovske rasprave i njihove sudionike, a što su imali snažan utjecaj na formiranje i razvoj Fichteova sustava transcendentalnog idealizma. Kao što već naznačih, takav je pristup problematici svakako nužan i važan jer uz naveliko obrađivanje općepoznatog utjecaja Immanuela Kanta, zatim samog duha vremena i sl. (koje ni Ježić ne izostavlja), na Fichteovo kristaliziranje filozofijske misli važan su utjecaj imali i različiti Kantovi sljedbenici i oponenti, njihova djela, recenzije, rasprave i sl.

Nakon toga slijedi poglavlje O Fichteovu jenskom sustavu transcendentalne filozofije, gdje se prvotno usmjerava pažnja na sam naziv Fichteova sustava. Naime, kao što je poznato, Fichte svojoj filozofiji, tj. svojem transcendentalnom idealizmu dodjeljuje naziv Wissenschaftshlehre, no Ježić ukazuje ne samo na to što se tim nazivom htjelo označiti, tj. na smisao kao i sama ishodišta i porive Fichteova stvaranja navedena termina, nego i na njegova pojedina (ne)shvaćanja, (ne)prihvaćanja i tumačenja u njegovih suvremenika. Tu se sva- kako nije radilo o razbacivanju neologizmom ili Fichteovoj želji za pukim pozicioniranjem nepoznatim terminom, nego, kako nam se u knjizi i dokumentira, o promišljenom i utemeljenom stavu. Naime, Fichte, ispravno, uočava da ljubav prema mudrosti (filozofija) nije nikakvo jamstvo znanja, posebice onog znanstvenog (u značenju termina Wissenschaft); dapače, kako se navodi, on smatra da će termin filozofija biti prevladan, pa upravo zato i insistira na onome što naziva Wissenschaftshlehre. Naravno, taj se termin različito prevodio i prevodi, i u nas i u svijetu, dok nam Ježić ukazuje na neka temeljna i najpoznatija prevodilačka rješenja kao i dileme, ali nudi i vlastiti prijevod. Naime, prevodeći po smislu, odnosno objašnjavajući te potkrjepljujući i samim Fichteovim iskazima, autor navodi kako se tu radi o znanosti o znanosti/znanju, a za što nudi zgodnu složenicu znanstvoslovlje, tako da na taj način pridonosi i domaćem filozofskom nazivlju.

Zatim se ukazuje na razvojnu karakteristiku znanstvoslovlja. Tu razvojnost Ježić naznačuje, navodeći kako Fichteovu filozofiju zapravo čini više nabačaja, tj. nedovršenih, iako intelektualno snažnih i opsežnih, prikaza, ili njihovih pokušaja, u kojima se temeljno ista stvar tijekom vremena sagledava na različite načine, ali se i razvija filozofijska misao do njezine karakterističnosti i složenosti. U tom kontekstu nabraja Fichteovih petnaest prikaza (nastalih u razdoblju od 1794. do 1814 . godine), dok svoju pažnju usmjerava na prvi i drugi, koje naziva ranim i kasnim jenskim prikazima znanstvoslovlja.

U svakom slučaju, prvi i temeljni prikaz znanstvoslovlja općenito se smatra najutjecajnijim i ishodištem svih ostalih Fichteovih prikaza (prvi je spis toga prikaza, objavljen kao O pojmu nauka o znanosti, na hrvatski jezik preveo Kiril Miladinov, dok je drugi objavljen u prijevodu Viktora D. Sonnenfelda kao Osnova cjelokupne nauke o znanosti). No taj važan Fichteov prikaz ima i neke bitne prethodeće momente, pa Ježić usmjerava pažnju na tri bitna teksta, naznačujući njihove temeljne doprinose, koja ne samo da mu prethode nego, kako to smatra, predstavljaju bitna izvorišta za razumijevanje nastanka i razvoja znanstvoslovlja. Tako se kao jedan od najznačajnijih navodi Fichteova recenzija iz 1794 ., kao i njezini nacrti, anonimno objavljenog djela Gottloba Ernsta Schulzea Aenesidemus ili o temeljima elementarne filozofije koju je $u$ Jeni izložio gospodin profesor Reinhold (1792.), u kojem Schulze propituje kritičku filozofiju. No ne samo što Ježić iznosi bitne elemente (npr. odnos prema Karlu Leonhardu Reinholdu) navedene recenzije u kontekstu shvaćanja Fichteove misli nego je posebna 
vrijednost to što nam u dodatku svoje knjige prilaže i njezin vrijedan prijevod! Dakle, na taj nam se način ne samo izravno nudi da $i$ sami provjerimo i spoznamo važnost navedenog dokumenta (poznato je da ga između ostalih hvali, tj. njegovu korist ističe i Friedrich W. J. Schelling /vidjeti Schelling, J. W. Friedrich: Ueber die Möglichkeit einer Form der Philosophie überhaupt/) za nastanak i razumijevanje znanstvoslovlja nego i da pokušamo prodrijeti u tadašnje Fichteovo stanje filozofijskoga duha. Kao ostala dva važna rukopisa, ili dva pretprikaza znanstvoslovlja, Ježić navodi tekstove Vlastite meditacije o elementarnoj filozofiji i Praktička filozofija, što su završeni 1794. godine. Naposljetku, navodi kako ti rukopisi nastaju u Švicarskoj (u kojoj se Fichte našao zbog ženidbe), gdje pred kraj boravka, i nakon poziva za preuzimanje predavačkog mjesta na Sveučilištu u Jeni, kao već priznati kantovac Fichte svima zainteresiranima svojim predavanjima približava kritičku filozofiju, ali i iznosi osnove znanstvoslovlja (zasigurno je najvažnije njegovo temeljenje na čistome jastvu). Također, na temelju onoga što je sačuvano, tj. zapisa Johanna Kaspara Lavatera, izvatka samih predavanja Jensu Baggesenu, ali i objavljenog Fichteova govora $O$ dostojanstvu čovje$k a$, Ježić usmjerava pažnju i na neke njihove bitne elemente i kako su, barem dijelom, bila strukturirana.

Nakon toga se naznačuje da je i u vrijeme svoje objave rani jenski prikaz smatran mračnim ( $\sigma \kappa o \tau \varepsilon ı v o ́ \varsigma)$ te da je bio loše prihvaćen od čitateljstva, a čega je bio svjestan i sam Fichte. Stoga, Fichte neupućenima (u znanstvoslovlje) savjetuje (kako nam se to i dokumentira) svoje kasnije prikaze, pa i radove svojega kolege Friedricha W. J. Schellinga. Inače, tu nejasnoću prvoga prikaza Ježić temeljno objašnjava (i dokumentira) utjecajem pokantovskih rasprava, ali i samom njegovom formom kao i Fichteovom terminologijom.

Nezadovoljan (ne)razumijevanjem prvog jenskoga prikaza, kao i općim odnosom prema njemu, Fichte se odlučuje na pisanje drugoga (Znanstvoslovlje po novoj metodi), u cilju razjašnjenja prvoga, sada svakako iskusniji i višegodišnjim predavanjima znanstvoslovlja ali i diskusijama s nekima što su ga čitali. Ježić posebno naznačuje i dokumentira didaktičku vrijednost, tj. napredak tog drugog jenskoga prikaza (što ga je Fichte predavao svojim studentima od 1796. do 1799. godine), objavljenog tek u 20. stoljeću, i to prije svega $\mathrm{u}$ izloženom postupku kojim Fichte usmjerava do samospoznaje odnosno uvida u apsolutnu samosvijest. Ovdje je svakako bitno uočiti koliku vrijednost za (samo)kritički nastrojenu osobu ima interakcija s drugima, a posebice mogućnost da se određeno znanje nastavom pokuša sročiti i približiti zainteresiranima.

Pažnja se zatim ponovno, ali nešto detaljnije, usmjerava na rani jenski prikaz znanstvoslovlja, tj. na ono na čemu se Fichteova filozofija zapravo i temelji. U tom kontekstu Ježić naznačuje kako se taj prikaz znanstvoslovlja zapravo sastoji od triju tekstova, jednog programskog $O$ pojmu znanstvoslovlja i dvaju izvedenih: Temelj cjelokupnoga znanstvoslovlja i Nacrt osobitosti znanstvoslovlja s obzirom na teoretičku moć, nastalih u kontekstu Fichteova nastavničkog početka na Sveučilištu u Jeni (dakle, očito je kako rani jenski prikaz znanstvoslovlja ne čini samo spis $T e-$ melj cjelokupnoga znanstvoslovlja, kako to šira javnost uglavnom smatra). Dapače, navodi nam njihove temeljne sadržaje, namjene, međusobne odnose kao i ključne stavke. Ježić opisuje i dokumentira da se zapravo radi o tekstovima što prvotno nisu bili namijenjeni objavi, pa tako navodi kako je prvi, il pozivni, imao namjeru pružiti temeljni uvid o onome o čemu će se predavati, ali i Fichteovim kolegama ili prijateljima poslužiti za prosudbu o znanstvoslovlju, dok su drugi i treći, kao neposredni proizvod prvih predavanja, trebali olakšati samo praćenje nastave. Taj je podatak bitan, kako to i autor naznačuje, čitatelju/ici kako bi im znao/la valjano prići i vrednovati ih kontekstno, odnosno za shvaćanje njihovih određenih manjkavosti, nedorečenosti, mračnosti i sl., kojih je bio (kao što je i naznačeno, a u ovom dijelu i dokumentirano), svjestan i sam Fichte. U svakom slučaju, kako se navodi, Fichte je tim predlošcima htio ne samo olakšati shvaćanje svojega znanstvoslovlja nego i slušateljstvo osloboditi zapisivanja, i time ih uključiti da aktivno s njime tijekom nastave "porađaju « (nažalost, takav je interaktivan i kreativan odnos nastavnika $i$ slušateljstva danas vrlo rijedak). Naposljetku, navode se još pojedini tekstovi proizišli iz jenskih predavanja te ukratko predstavlja spis Nekoliko predavanja o određenju učenjaka, za koji Ježić naznačuje da ulazi u prvi prikaz znanstvoslovlja.

Na kraju ovoga poglavlja, autor se osvrće na grananje Fichteove filozofijske misli, odnosno tek temeljno na raniju (nesustavniju) i nešto detaljnije na kasniju (sustavniju) Fichteovu podjelu znanstvoslovlja, uz koju približava i kratak opis i značenje izvedenih dijelova. U tom se kontekstu navode i kratko prikazuju i tekstovi u kojima Fichte manje ili više razrađuje određena filozofijska područja (prirodno pravo, etiku, filozofiju religije, estetiku) i nakon jenskoga razdoblja, te se naznačuje kako su za njegova života vjerojatno bili najbolje prihvaćeni Temelj prirodnoga prava prema načelima znanstvoslovlja, iz 1797., i 
Sustav etike prema načelima znanstvoslovlja, iz 1798. godine. Ovdje je zanimljivo uočiti, kako nam se to i dokumentira, da se Fichte prema svojem prvijencu Pokušaj kritike svake objave (1792., 1793.) vrlo kritički i s nezadovoljstvom odnosi, a što vjerujem da je iskustvo gotovo svakog/e ozbiljnijeg/e mislitelja/ ice, ali i dobar primjer potrebe sazrijevanja i razvoja misli, kao i samokritičnosti.

U trećem poglavlju Odnos Fichtea spram njegovih neposrednih filozofijskih prethodnika, uz nekoliko crtica iz Fichteova života (npr. par temeljnih biografskih podataka o Fichteovoj mladosti, pa tako između ostaloga o njegovu školovanju i nikad završenom studiju teologije/koji su mu financirani od strane mecene/, siromaštvu kroz koje prolazi, zarađivanju /u Leipzigu i Zürichu/ kao kućni učitelj itd.), Ježić temeljno predstavlja Kanta i glavne aktere (kao i njihove temeljne doprinose) pokantovskih rasprava kao i Fichteov odnos s njima te stanje i odnose u tadašnjoj njemačkoj filozofiji, sve to kao bitne elemente nastanka i/ili razvoja znanstvoslovlja. No u nastavku se, u kontekstu ovoga poglavlja usmjeravam samo na ono što je tijesno vezano za Fichtea.

Tako se navodi da je Fichte prije susreta s Immanuelom Kantom gajio determinističko-deistički pogled, a što nam se približava i kratkim osvrtom na njegov spis Aforizmi o religiji i deizmu iz 1790. godine (čiji prijevod, kako već navedoh, u dodatku svoje knjige Ježić prilaže). Također, Ježić navodi kako je prvo ozbiljnije Fichteovo bavljenje s Kantom bilo kada je kao kućni učitelj zamoljen pružiti poduku iz Kantove Kritike čistoga uma, no da je prijeloman utjecaj na njega poučila tek Kritika praktičkoga uma, a što se dokumentira i samim Fichteovim riječima. Nadalje, skreće se pažnja na Fichteova dva za života neobjavljena spisa u kojima prikazuje i komentira transcendentalnu logiku Kritike čistoga uma i uvodni dio Kritike rasudne snage, koju je smatrao posebno vrijednom i jasnije napisanom od prve dvije Kritike, odnosno koja mu je bila podosta poticajna, a što je, kako nam se i dokumentira, Fichte priznao i samom Kantu. Zatim se pažnja usmjerava na Fichteovo djelo Pokušaj kritike svake objave koje je, kako se naznačuje, pisano pod bitnim utjecajem Kantove filozofije, i čiji nacrt Fichte pokazuje i samom Kantu. Ježić navodi kako zahvaljujući upravom tom djelu Kant preporučuje Fichtea vlastitom königsberškom izdavaču, i tako omogućuje njegovu objavu 1792. godine, te ga preporučuje i za kućnog učitelja u Danzigu. Zatim se skreće pažnja na to kako je Pokušaj kritike svake objave dočekan s oduševljenjem i naveliko hvaljen, ali zbog toga što je čitateljstvo bilo uvjereno da se radi o novom Kantovu djelu jer nakladnik (hotimice ili nehotice) nije naveo tko je autor djela, niti objavio Fichteov predgovor knjizi. No bez obzira na to, nakon što Kant javno obznanjuje tko je autor (što nam se i dokumentira), Fichte zahvaljujući navedenom djelu stječe širi ugled te dobiva važnu poziciju nastavnika na jenskom sveučilištu. Naposljetku, Ježić prikazuje i bogato dokumentira kakav je zapravo bio odnos Fichtea i Kanta, odnosno ukazuje na ne samo Kantov (ali i još pokojeg kantovca) stav o znanstvoslovlju nego i koliko i kakvo je vjerojatno bilo Kantovo poznavanje Fichteova sustava.

Zatim se navodi i dokumentira Fichteovo izrazito poštovanje filozofijske misli Friedricha Heinricha Jacobija, odnosno kako je samog Jacobija smatrao najznačajnijim misliteljem toga vremena. Također, naznačuje se i Jacobijevo, posebice prvotno, oduševljenje Fichteom i znanstvoslovljem. Nakon toga približava se Fichteov napor oko uspostavljanja njihova kontakta (pismima i šaljući Jacobiju svoje spise), dapače, njegovo isticanje usuglašenosti spekulativne filozofije i zdravorazumskog realizma te nadu u njihovo savezništvo. No Ježić je suzdržan oko teze da je Jacobijeva misao, bez obzira na određene sličnosti, bila ishodište pri nastanku znanstvoslovlja (jer uostalom na Jacobija se Fichte počinje pozivati od 1796. godine), iako naznačuje njezinu poticajnu ulogu (npr. Jacobijeva kritika Kantove stvari o sebi), ali vjerojatno i značenje za Fichteovo upoznavanje s npr. Spinozinom filozofijom. Uz ostalo, temeljeći se na Jacobijevu otvorenom pismu Fichteu iz 1799. godine autor ukazuje na pojedine sličnosti i razlike znanstvoslovlja i Jacobijeve misli, posebice njihovo neslaganje pa i nesporazum oko Boga. No ovdje bih upozorio na jednu previše smjelu tvrdnju, a to je da Jacobi uvodi pojam nihilizam (kojemu po njemu vodi Fichteov idealizam, svojim tumačenjem onog empirijskog kao pukog proizvoda svijesti). Naime, bez obzira na to što je vrlo često teško znati tko je što prvi uveo ili definirao, dokumentirano je (vidjeti npr. Mario Kopić /2001/, $S$ Nietzscheom o Europi, posebice poglavlje »Nihilizam kao usud?«) kako se navedeni termin koristio i ranije.

Ježić nakon toga usmjerava pažnju na odnos i prepiske između Fichtea i Karla Leonharda Reinholda, važnog popularizatora Kantove filozofije, a čije mjesto Fichte s izazovom (s obzirom na Reinholdovu predavačku slavu) preuzima na Sveučilištu u Jeni. Tako nam se približavaju neki važni elementi njihove prepiske, kao vrijednog uvoda u Fichteovu misao i razumijevanje prvoga prikaza znanstvoslovlja, ali i naznačuju pojedini Reinholdovi radovi, bitni i poticajni za razradu Fichteove misli. 
Svakako treba navesti, kako Ježić ukazuje, da Reinhold nije bio samo važan za Fichteovo dublje razumijevanje Kantova idealizma, nego je svojom recenzijom Fichteovih ranih jenskih djela (koja uključuje i kritičku usporedbu Fichteove i Katove misli) potaknuo Kantovu pažnju i upoznao ga sa znanstvoslovljem.

Zatim se predstavlja odnos između Fichtea i njegova nekadašnjeg školskog i studentskog kolege Gottloba Ernsta Schulzea, i to izvan konteksta onoga što Fichte iznosi u svojoj recenziji Aenesidemusa. Tako Ježić navodi kako je Schulze napisao prvu (anonimnu) negativnu recenziju Fichteova Pokušaja kritike svake objave te naznačuje same okolnosti objave kao i prve reakcije na navedeno Fichteovo djelo. Dapače, prikazuje i sadržaj recenzije (što vlastitim komentarima što izravnim prikazima dijelova recenzije), naznačujući glavnu Schulzeovu zamjerku Fichteu: povezivanje moralnosti s Božjom voljom (ovdje se navode i Schellingov i Hegelov stav o tom problemu, tj. o onome što se iz njega izvodi). Naposljetku, dokumentira se kako je Fichte priznao određene Schulzeove zamjerke te se naznačuje i dokumentira koju je važnu, reklo bi se i presudnu ulogu za izgradnju filozofije kao znanosti iz jednog temeljnog načela, odnosno za nastanak znanstvoslovlja imao i Schulzeov Aenesidemus, koji je Fichte i recenzirao te, vjerojatno, na temelju kojega i prepoznaje samog autora recenzije.

Započevši naznakom Ernsta Cassirera o njihovoj važnoj povezanosti, Ježić (inače, prvi za sada jedini prevoditelj nekog Maimonova spisa na hrvatski jezik) se usmjerava na odnos između Fichtea i Salomona Maimona. U tu svrhu iznosi izvatke pisama, naznačuje Fichteove tekstove u kojima spominje ili se poziva na Maimona te se usmjerava na sadržajne sličnosti (pri čemu se poziva na stav kako se radi o utjecaju Maimona na Fichtea) ili naprosto samo podudarnosti njihove misli. U tom se kontekstu ukratko osvrće i na neka zbunjujuća Fichteova pozivanja na Maimona, odnosno očito omaške i nerazumijevanja, te nas usmjerava na jedno od logičnijih objašnjenja takva propusta. Također, Ježić iznosi pojedina mišljenja o tome s kojima je to Maimonovim tekstovima Fichte vjerojatno bio upoznat, tj. koje je pročitao, ali navodi i još neke za koje vjeruje da ih je Fichte također čitao, odnosno za koje smatra da su bili važni pri stvaranju znanstvoslovlja. Isto tako, kratko se naznačuje temeljna razlika Fichteova i Maimonova pristupa filozofiji te ukazuje kako je vjerojatno Maimon, uz Schulzea, glavni poticatelj Fichteova iščitavanja Humeove filozofije, a samim time i drugačijeg razumijevanja unutrašnjeg razvoja Kantove kritičke filozofije.
Naposljetku, Ježić predstavlja Fichteov odnos s Carlom Christianom Erhardom Schmidom i Jacobom Sigismundom Beckom, istaknutim ondašnjim kantovcima. Dakle, s jedne strane, ukratko se prikazuje kako je Fichte prvotno ušao u komunikaciju s prvom recenzijom djela Skeptička razmatranja o slobodi volje s obzirom na najnovije teorije o njoj Leonharda Creuzera (za koje je Schmid napisao predgovor), u kojoj se kritički osvrće i na Schmidov inteligibilni fatalizam, $\mathrm{tj}$. promišljanje o moralnosti i slobodnoj volji, te zatim na njihovu raspravu nakon što su postali kolege na Sveučilištu u Jeni. U tom se kontekstu naznačuje i dokumentira Schmidov značaj na Fichteovo pažljivo razrađivanje djela O pojmu znanstvoslovlja te kako njihova rasprava iz 1796. godine u Filozofijskom časopisu društva njemačkih učenjaka, između ostaloga, sadrži i prvi Fichteov prikaz pojma subjekt-objekt, odnosno polazište i postupak drugog (kasnog) jenskoga prikaza Znanstvoslovlja po novoj metodi. Naposljetku, ukratko se dokumentira i okončanje njihova odnosa Fichteovim činom Schmidova svojevrsnog anihiliranja. S druge strane, nakon kratkog predstavljanja kantovca i Kantova učenika Becka (svojevrsnu stubu između kritičke filozofije i znanstvoslovlja), naznačuje se i dokumentira kako je treći dio njegova Objasnidbenoga izvatka iz kritičkih spisa g. prof. Kanta, na njegov nagovor, tj. Jedino moguće stajalište s kojega se kritička filozofija mora prosuđivati iz 1796. godine Fichte smatrao ponajboljom pripremom onima što su zainteresirani za znanstvoslovlje i to, prije svega, zbog Beckova stajališta o stvari o sebi.

U poglavlju Problemi u razvoju znanstvoslovlja u kontekstu rasprava Fichteovih neposrednih filozofijskih prethodnika prvo se ukazuje na Fichteov stav o odnosu između tzv. zdravorazumskog i filozofijskog mišljenja. Dapače, Ježić naznačuje kako je to prva tema znanstvoslovlja, pa i svojevrsno ishodište formiranja idealizma, te da se njome Fichte manje ili više bavi u većini svojih djela (posebice tijekom tzv. spora oko ateizma). Prikazuje se Fichteov stav da su navedena dva mišljenja, tj. područja (objektivno i subjektivno), iako se radi o potpunoj antitezi, ipak međuovisna. Odnosno, da se zdravorazumsko, objektivno, realno ili sl. istinski može shvatiti, protumačiti i misaono postaviti samo idealizmom, odnosno filozofijskom spekulacijom.

Zatim se propituju idejne sličnosti i razlike između Fichteova znanstvoslovlja i Kantova transcendentalnog idealizma. U tom se kontekstu Ježić prvo prima Kritike čistoga uma, odnosno njezina tumačenja. Tako neke njezine temeljne stavke i reakcije na nju ukratko predstavlja preko tzv. Göttingenske recenzije 
Kritike čistoga uma (1782.), Christiana Garvea i njezina »redaktora« Johanna Georga Heinricha Federa (koju je Ježić prvi preveo na hrvatski jezik, a prijevod objavio u časopisu Holon), osvrta Moje predodžbe (1782.) $\mathrm{i}$ dodatka $» \mathrm{O}$ transcendentalnom idealizmu teksta David Hume o vjeri ili idealizam i realizam (1787.) Friedricha H. Jacobija, a s kojima je, kako nam se i dokumentira, Fichte bio upoznat.

Pažnja se nakon toga usmjerava na Fichteov stav kako je njegov sustav u biti identičan Kantovu transcendentalnom idealizmu. U tu svrhu, odnosno za prikaz sličnosti ili manje razlike znanstvoslovlja i Kantova sustava Ježić iznosi temeljne Fichteove ideje iz njegove dvije rasprave u kojima se poziva na spomenuti Jacobijev tekst $\gg \mathrm{O}$ transcendentalnom idealizmu «. Tako nam iz prve, $\mathrm{tj}$. Usporedbe Schmidova sustava sa znanstvoslovljem (1796.), ukratko skreće pažnju na Fichteovo tumačenje realizma i idealizma u Kritici čistoga uma, ali i upozorava na očito Fichteov propust prilikom pozivanja na navedeni Kantov spis. Dok nam iz druge, tj. Drugi uvod u znanstvoslovlje (1797.), prikazuje Fichteov dokaz za njegovu tvrdnju o istosti znanstvoslovlja i Kantova transcendentalnog idealizma. U ovom nešto opširnijem dijelu autor, osim što prikazuje neka Fichteova (ne)shvaćanja i tumačenja dijelova Kantova sustava, također ukazuje na to kako Fichte, pozivajući se uz Kanta na Jacobija i Schulzea, smatra da su gotovo svi značajniji rani kantovci neispravno razumjeli Kantov idealizam i to u kontekstu primjenjivosti kategorija i stvari o sebi. Dapače, u ovome se odjeljku detaljnije usmjerava pažnju i objašnjava, pozivajući se na Kanta, Schulzea i Reinholda, određena razlika između transcendentalnog predmeta i stvari o sebi i noumena, a koja se ne samo i danas često previđa, ili je neki naprosto smatraju problematičnom, nego su je očito brkali i Jacobi i Fichte.

Nadalje, Ježić ukratko prikazuje, temeljeći se na prvom izdanju Kritike čistoga uma, specifičnosti različitih vrsta idealizama, odnosno razlike Kantova naspram ostalih: empirijskog, skeptičkog i dogmatičkog. Tako naznačuje kako bi se, uz Kantov, transcendentalnim idealizmom na svoj način mogao nazvati onaj Reinholdov, da su Maimonovo, a nešto labavije, i Schulzeovo stajalište kritički skepticizam, koji je manjim dijelom usporediv sa skeptičkim idealizmom, te naposljetku da je Fichte svoj idealizam, kao nešto što je između dogmatičkoga idealizma i transcendentnog realističkoga dogmatizma, nazivao kritičkim, tj. da je naveo kako ga se može zvati i idealrealizmom ili real-idealizmom.

Zatim se ističe da, bez obzira na vjerojatno samostalno sazrijevanje Fichteove misli, kao i utjecaj raznih kantovaca i skeptika (posebice Maimona), za nastanak znanstvoslovlja krucijalan značaj ima Schulze, a što Ježić navodi da se često previđa. Naime, kako se to ukazuje (npr. za određene stavke i dijelovima Fichteova pisma svojemu bivšem profesoru Reinhardu), rad na recenziji Aenesidemusa potiče Fichtea na promišljanje o određenim nedostacima Kantova idealizma kao i na napuštanje Reinholdova sustava Kantova idealizma, ali i na izgradnju vlastita »održivijega« idealizma, što se temelji na apsolutnome subjektu. Tako autor naznačuje da u razdoblju od početka ozbiljnijeg rada na recenziji (studeni 1793.) Fichte stvara i Vlastite meditacije o elementarnoj filozofiji (koje dorađene objavljuje u prvom prikazu znanstvoslovlja), te da su i u samoj recenziji po prvi put naznačene bitne karakteristike njegova idealizma (a što čitatelji/ice mogu i sami provjeriti budući da nam knjiga, kao što već naznačih, donosi i sam prijevod recenzije). Također, ukratko su prikazane i neke konkretne teme iz Aenesidemusa (npr. Schulzeova promišljanja o stvari o sebi, o nužnosti u našim predodžbama) koje Ježić smatra da su Fichteu mogle biti bitan poticaj za stvaranje ili razrađivanje vlastite misli.

Ježić nakon toga usmjerava pažnju na Fichteovo pronalaženje temeljne postavke ili načela po kojem bi filozofija bila znanost, odnosno znanstvoslovlja kao znanosti svih znanosti. U tom kontekstu ukratko prikazuje Fichteovo promišljanje, tj. s tom problematikom temeljno povezane stavke (npr. predmet filozofije kao znanosti, o pojmu i biti znanosti, tj. što znanost čini znanošću, materiji i formi znanstvoslovlja) iz njegova programskog teksta $O$ pojmu znanstvoslovlja. Kako nam naznačuje, $\mathrm{u}$ navedenome se nastojanju Fichte uglavnom temeljio na Kantovoj kritičkoj filozofiji, Reinholdovoj elementarnoj filozofiji, tj. njegovu pokušaju znanstvenog utemeljenja Kantove filozofije, kao i Maimonovim tekstovima u kojima kritizira navedeni Reinholdov pokušaj, ali i onima o određenju filozofije (kao znanosti).

Nakon toga se prikazuje Reinholdova temeljna postavka ili načelo svijesti, u kontekstu čega se navodi njezinih šest uvjeta te dijelovi njezine kritike iz Aenesidemusa, kao i Maimonovo polazište, tj. napomenu i prigovor postavci. U svakom slučaju, u ovom se dijelu Ježić osvrće na one prigovore što ih je Fichte prihvatio i njezina rješenja naznačio u svojoj recenziji Aenesidemusa, a koje je u djelima $O$ pojmu znanstvoslovlja i Temelj cjelokupnog znanstvoslovlja, kao dijelove svojega sustava razradio. Naposljetku, naznačeni su i dodatni razlog i motiv zašto Fichte ne prihvaća Reinholdovo načelo svijesti, kao temeljno filozo- 
fijsko načelo, odnosno nejasnoću o odnosu ishodišne predodžbe i nepredočive težnje za apsolutnim jedinstvom (iskazane $\mathrm{u}$ Fichteovu ishodišnu načelu: Ja jesam Ja).

Sve to vodi do petog poglavlja, Temelj Fichteova ranoga jenskoga prikaza znanstvoslovlja, u kojem se jasno približavaju Fichteove tri temeljne postavke ili načela znanstvoslovlja. Dakle, prvu, ishodišnu, temeljnu postavku svih temeljnih postavki koja glasi: »Ja jesam naprosto«, a za koju naznačuje da je neuvjetovana po sadržaju i po formi, prethodi svakoj sintezi te predstavlja očitovanje činjenja samog duha (koji je sam taj čin), a ne puke činjenice. U tom kontekstu Ježić navodi kako se ovdje Ja ne odnosi na osobno ja, nego na čisto Jastvo, te razlog zašto se Fichte odlučuje za termin jastvo, a ne sepstvo. U svakom slučaju, navodi se i Fichteovo objašnjenje kako se izvjesnost prve temeljne postavke izvodi iz logičkog načela istovjetnosti $» \mathrm{~A}=\mathrm{A} \ll$. Zatim drugu, antitetičku, temeljnu postavku, koja je uvjetovana prvom po sadržaju ili materiji, i koja glasi: »Jastvu je naprosto protupostavljeno neko Ne-Jastvo«, a koja svoju izvjesnost izvodi iz logičkog načela proturječja: »-A nije $=\mathrm{A} \ll$. Naposljetku i treću, sintetičku, temeljnu postavku koja glasi: »Ja postavljam u Jastvu nasuprot djeljivom Jastvu neko djeljivo $\mathrm{Ne}$ Jastvo ili »Ja protupostavljam u Jastvu djeljivomu Jastvu neko djeljivo Ne-Jastvo«, koja je uvjetovana formom prvih dviju temeljnih postavka ili načela. Dakle, trećom se, »pomirujućom «, postavkom, kako to Ježić naznačuje, dobiva logičko načelo razloga: »A je dijelom = -A, i obrnuto «, ali i izvode postavke: a) teoretičkog znanja: »Jastvo se postavlja kao ograničeno/određeno Ne-Jastvom« i b): znanosti praktičkoga: »Jastvo postavlja $\mathrm{Ne}$ Jastvo kao ograničeno/određeno Jastvom«.

Naposljetku, prije zaključnog poglavlja, u kojem rekapitulira svoju knjigu te pobrojava koje to glavne pobude smatra da su Fichteu u temeljnoj izgradnji znanstvoslovlja pružile Jacobijeva, Reinholdova, Schulzeova i Maimonova filozofska misao, Ježić sažimajući ističe samu bit Fichteova filozofijskog sustava. Tu ću bit približiti izravnim Fichteovim riječima, koje se u knjizi citiraju, da »se sve što se zbiva u duši može potpuno objasniti i pojmiti iz nje same« $\mathrm{i}$ da:

»Djelovanje o kojem je ovdje riječ jest, kao uvijek, tek čisto idealno, po predodžbi. Čak nam ni naša osjetilna djelotvornost u osjetilnome svijetu, u koju vjerujemo, ne pridolazi drugačije doli posredno po predodžbi.«

Na samom kraju ovoga osvrta, naznačio bih kako se nadam da Ježićev informativan i bogato dokumentirani prvijenac predstavlja tek početak njegova rada na znanstvoslovlju, odnosno početak detaljne analize, tumačenja, kontekstualiziranja, problematiziranja i sl. same Fichteove filozofijske misli, odnosno njezinih pojedinih tematskih područja, jer takvo što ne samo da manjka, posebice u Hrvatskoj, nego ova knjiga na svoj način i zaziva.

\section{Vanja Borš}

\section{doi: $1021464 /$ fi3 3214}

\section{Davor Balić}

\section{Etički nauk Marka Marulića}

\section{Hrvatska akademija znanost i umjetnosti, Zagreb - Križevci 2016.}

Knjiga Etički nauk Marka Marulića, nastala, kako autor napominje, kao rezultat znatnije dorađenog i proširenog teksta doktorske disertacije obranjene 2011. godine, otkriva, ne samo svojim impozantnim opsegom nego i intrigantnom naslovnicom, da je riječ o izdanju osobite vrijednosti i značenja. Vrlo preciznom, akribičnom znanstvenom analizom Marulićevih djela, ali i, danas već gotovo nepregledne, sekundarne literature, Davor Balić daje sustavan i pregledan uvid u nepoznate $i$ one manje poznate segmente Marulićeva promišljanja.

Nema sumnje da je dugogodišnji rad predanih marulologa $\mathrm{s}$ jasnom $\mathrm{i}$ iskrenom vizijom pred sobom doprinio (a to, dakako, čini i dalje) boljem poznavanju života i djela istaknutog hrvatskog renesansnog mislioca, čije se ime krije pod već dobro znanom sintagmom »otac hrvatske književnosti«. Međutim, mnogobrojni istraživači Marulićeva opusa svoj su interes usmjerili pretežito na njegove književne i teološke misli i poruke. Pritom su filozofski elementi, odnosno etički segmenti njegova djela ostali poprilično marginalizirani. Kritičkim pregledom znanstvenih priloga u kojima njihovi autori (V. Filipović, Lj. Schiffler, B. Jozić, D. Šimindža, N. Stanković, J. Talanga, B. Glavičić, E. Banić-Pajnić, I Martinović, I. Grgić) sagledavaju filozofske segmente Marulićeva djela, odnosno »problematiku koja se u Marulićevim djelima odnosila na filozofsku etiku « (str. 3), Balić zaključuje da »Marulićeva etička misao dosad nije proučena ni vrednovana u cijelosti, zbog čega nedostaju i prosudbe o Marulićevu odnosu prema etici kao filozofskoj disciplini« 